\title{
Usage of project management methods, tools and techniques in infrastructure projects
}

\author{
Mariela Sjekavica Klepo ${ }^{\mathrm{a}}$, Mladen Radujkovićb \\ ${ }^{a}$ Croatian Water (Hrvatske vode), Ulica grada Vukovara 220, Zagreb 10000, Croatia \\ ${ }^{b}$ Alma Mater Europea ECM, Slovenska ulica 17, Maribor 2000, Slovenia
}

\begin{abstract}
We are witnesses of projectification of our world. Projects are evolving daily, in faster, bigger and more complex manner, requiring project management to adjust to these changes adequately. One of the major help project managers and their teams have in decision making, planning, monitoring, organizing and doing their everyday activities in general are set of different project management methods, tools and techniques. They are supposed to increase overall project success, which is often not the case, especially on projects of large infrastructure nature. The main aim of this article is to investigate which project management methods, tools and techniques, as well as project management methodologies and standards, managers of infrastructure projects use (due to their company and/or project requirements, knowledge or habits) in accordance to their perceived usefulness in context of Republic of Croatia. This kind of research may help in better targeting of those project management tools that really do make the difference in special contexts. This is especially important in world where added value to projects fulfilment is appreciated more than ever. Methodology used in this research was comprehensive literature review on the field, survey and statistical analysis. Results of the research may be useful both to project management scientists in directing their future research on the field, as well as project management practitioners and educators in usage and development of knowledge, skills and experience of working with the most effective methods, tools and techniques.
\end{abstract}

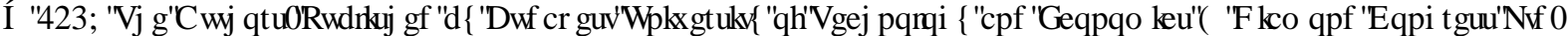

Peer-review under responsibility of the scientific committee of the Creative Construction Conference 2019.

Keywords: infrastructure projects; methodology; methods; project management; techniques; tools.

\section{Introduction}

Projects are becoming more challenging than ever before with the evolution of globalization, political realignments and rapid advance of information within firms [1] as well as general growth of economic and social demands. An effective strategy for overcoming those challenges may be found in engagement of information technology (IT) solutions in project management profession, which is already happening in development of virtual teams or application of neural networks. However, main problems of IT solutions remain the well-known "garbage in = garbage out" [2], so they remain only a category within the area of possible project management methods, tools and techniques (MTTs). MTTs seem to be an important project success factor. The application of the best standards and MTTs on project has positive effects on the overall project success [3]. Many projects fail to fulfil targeted budget, deadline or quality requirements, as well as overall project goals and contribute to organizational strategy. This problem is in focus on a special way if we talk about large infrastructural projects, which have even larger set of project success criteria to fulfil 
Mariela Sjekavica Klepo, et al. / Proceedings of the Creative Construction Conference (2019) 070 https://doi.org/10.3311/CCC2019-070

than those of "iron triangle". Therefore, it is purposeful and meaningful to find out how can project management MTTs and best praxes help project managers in leading their complex project endeavours towards successful outcomes. The main aim of this research is to find out which project management MTTs, as well as project management methodologies or standards, project managers use in managing infrastructure projects, as well as how useful they consider them to be. The fulfilment of the research goal will contribute in building awareness of relationship between usage and usefulness in order to direct future performances on the field. The goal is reached throughout research methodology explained below.

First step was to define relevant MTTs, methodologies and standards used in today's world of project management. This was undertaken through desk research - literature review of the relevant publications on the field. Then, a survey was undertaken within one group of infrastructural project managers - those of water projects. The sample was asked to give their insights on the level of usage and usefulness (efficiency) of each of methodology, standard, and MTT from the list created in the first step. In addition, they were asked whether they think that some new solutions on this field are needed while managing projects. The results of the survey are given as an output of descriptive statistical analysis and grouping within categories of those inputs that are used most often, frequently, and rarely. Research results are then elaborated in context of today trends, other researchers work, and answers on the meaning of the picture of present state on the field. Finally, conclusion remarks and guidelines for further research are given.

\section{Literature review}

Project management methodologies and MTTs are significant project management success factor, and therefore, one of the enablers of project success [3]. Project management methodology is usually defined as a set of methods, techniques, procedures, rules, templates, and best practices used on a project. It is commonly based on a specific project management approach, that defines a set of principles and guidelines, which then define the way a project is managed [4]. The most common and well-known project management methodologies and standards within European context (especially in South East Europe) are PMI's Project Management Body of Knowledge [5] and IPMA's International Competence Baseline [6]. While using a certain methodology (or while managing a project without the official one), project managers must use some of project management tools and techniques, in order to fulfil their tasks and manage projects more effectively, organize their work, gather data and communicate.

There are numerous project management methodologies and MTTs nowadays. In order to find out an initial list of those that will be tested, authors did a comprehensive literature review. For the need of this research, the division of [7], followed by [8], which authors presented in their work as one element of project management success factors breakdown [3], was taken. Ref. [7] divided methodologies and MTTs for project management on six groups: project management methodologies, project management software, project management tools, decision-making techniques, risk assessment tools and information communication technology (ICT) support tools. From the initial [7]'s list, some elements were taken out, because they were not applicable in national context. Also, some of the elements that may had been significant in this context were added based on the review of relevant literature [9-12], forming the final list which was then an input to a questionnaire. Which of these methodologies, standards and MTTs are used, and which is their usefulness in context of water projects, was tested through empirical part of the study.

\section{Survey and results}

Total number of 31 water infrastructure projects managers answer the questionnaire on usage and usefulness of MTTs. They were gathered based on snowball sampling, with the first 10 gathered within national government agency for water management. They were asked to fill the questionnaire up and distribute it to the people they thought were the most competent to answer. By sampling like this, the survey was also answered by the project managers working in utility companies, contractors and consultants as well. Most of the respondents were male (65\%), between 31 and 40 years old (45\%), owning university degree (84\%), and had construction educational background (72\%). Averagely, 
Mariela Sjekavica Klepo, et al. / Proceedings of the Creative Construction Conference (2019) 070 https://doi.org/10.3311/CCC2019-070

respondents had 12 years of working experience, in which they worked on 6 projects. Average managed project lasted for 3 years and had financial value of 16.7 billion EUR.

Respondents were asked if they think that used methodologies, standards and MTTs on water projects are adequate in the sense of fulfilment of needs of water sector. Detailed results on this may be found in [13]. Then, respondents were given a list created through literature review (Chapter 2) in which they were supposed to check what they use and grade their usefulness/efficiency on Likert scale from 1 to 5 (where $1=$ extremely not useful; $2=$ not useful; $3=$ nor not useful, nor useful; 4 = useful; $5=$ extremely useful). Results were then divided onto three groups of methodologies, standards and MTTs: most often used (used by 13 respondents and more), frequently used (used by 5 to 12 respondents), rarely used (used by 4 respondents and less). The results are presented in Table 1 . These tables combine data on $\mathrm{M}$ - mean grade of usefulness and frequency $f(n)$ - number of units in the sample using a given element. Detailed additional statistics may be found in [13].

Table 1. Perceived usefulness of used methodologies, standards, methods, tools and techniques

\begin{tabular}{|c|c|c|c|c|c|c|c|c|}
\hline $\begin{array}{l}\text { Most often used methodologies, } \\
\text { standards and MTTs }\end{array}$ & M & $f(n)$ & $\begin{array}{l}\text { Frequently used methodologies, } \\
\text { standards and MTTs }\end{array}$ & M & $f(n)$ & $\begin{array}{l}\text { Rarely used methodologies, } \\
\text { standards and MTTs }\end{array}$ & M & $f(n)$ \\
\hline $\begin{array}{l}\text { Integrated groupware (e-mail, } \\
\text { collaborative tools, shared access } \\
\text { to web portals, etc.) }\end{array}$ & 4.39 & 31 & $\begin{array}{l}\text { Other decision-making } \\
\text { techniques and tools }\end{array}$ & 4.14 & 7 & Agile board & 4.50 & 2 \\
\hline Lessons learned & 4.38 & 13 & Team building activities & 4.00 & 10 & Decision trees & 4.50 & 2 \\
\hline MS Excel & 4.29 & 31 & Decision analysis - DA & 4.00 & 6 & $\begin{array}{l}\text { "In house" risk assessment } \\
\text { tools }\end{array}$ & 4.00 & 4 \\
\hline Cost benefit analysis - CBA & 4.17 & 18 & Sensitivity analysis - SA & 4.00 & 5 & Trend and variation analysis & 4.00 & 3 \\
\hline Reporting system & 4.05 & 22 & Communication plan & 3.91 & 11 & $\begin{array}{l}\text { Earned value management - } \\
\text { EVM }\end{array}$ & 4.00 & 2 \\
\hline Oracle Primavera & 4.00 & 16 & $\begin{array}{l}\text { "In house" project management } \\
\text { tools }\end{array}$ & 3.91 & 11 & $\begin{array}{l}\text { Critical chain method - } \\
\text { CCM }\end{array}$ & 4.00 & 1 \\
\hline Groupware (e-mail only) & 3.94 & 18 & $\begin{array}{l}\text { Voice over internet protocol (e.g. } \\
\text { Skype) }\end{array}$ & 3.91 & 11 & Delphi method & 4.00 & 1 \\
\hline Gantt bar charts & 3.93 & 27 & $\begin{array}{l}\text { Project management software } \\
\text { developed "in house" }\end{array}$ & 3.86 & 7 & Resource leveling & 4.00 & 1 \\
\hline Risk assessment & 3.92 & 13 & $\begin{array}{l}\text { Work breakdown structure - } \\
\text { WBS }\end{array}$ & 3.86 & 7 & $\begin{array}{l}\text { Other risk assessment tools } \\
\text { and techniques }\end{array}$ & 3.75 & 4 \\
\hline Progress meetings & 3.90 & 31 & Other project management tools & 3.83 & 6 & $\begin{array}{l}\text { "What-if" scenario analysis } \\
\text { - Cause and effect diagrams }\end{array}$ & 3.67 & 3 \\
\hline Cash flow analysis & 3.90 & 20 & Microsoft Project & 3.75 & 8 & $\begin{array}{l}\text { PMBOK® (Project } \\
\text { Management Body of } \\
\text { Knowledge) }\end{array}$ & 3.50 & 4 \\
\hline $\begin{array}{l}\text { "In house" communication and } \\
\text { reporting system }\end{array}$ & 3.89 & 18 & Critical path method - CPM & 3.75 & 8 & SAP & 3.50 & 2 \\
\hline Checklist analysis & 3.87 & 23 & $\begin{array}{l}\text { Other information } \\
\text { communication technology (ICT) } \\
\text { support tools }\end{array}$ & 3.73 & 11 & Monte Carlo simulation & 3.50 & 2 \\
\hline Progress reports & 3.86 & 29 & Life-cycle cost analysis (LCC) & 3.71 & 7 & Reliability analysis & 3.50 & 2 \\
\hline $\begin{array}{l}\text { PM methodology developed "in } \\
\text { house" }\end{array}$ & 3.74 & 19 & Video conferencing & 3.71 & 7 & $\begin{array}{l}\text { Other project management } \\
\text { software }\end{array}$ & 3.33 & 3 \\
\hline Trend diagrams/ $\mathrm{S}$ curves & 3.71 & 14 & $\begin{array}{l}\text { Other project management } \\
\text { methodologies }\end{array}$ & 3.70 & 10 & Probability and effect matrix & 3.33 & 3 \\
\hline \multirow[t]{2}{*}{ Project goals charter } & 3.67 & 15 & $\begin{array}{l}\text { Strengths, weaknesses, } \\
\text { opportunities and threats analysis } \\
\text { - SWOT }\end{array}$ & 3.60 & 10 & $\begin{array}{l}\text { ISO 21500:2012 - Guidance } \\
\text { on project management }\end{array}$ & 3.00 & 3 \\
\hline & & & $\begin{array}{l}\text { Project evaluation and review } \\
\text { technique - PERT }\end{array}$ & 3.60 & 5 & Stakeholder analysis & 3.00 & 3 \\
\hline
\end{tabular}


Mariela Sjekavica Klepo, et al. / Proceedings of the Creative Construction Conference (2019) 070 https://doi.org/10.3311/CCC2019-070

$\begin{array}{llllll}\text { Flow diagrams } & 3.60 & 5 & \text { Fault tree analysis (FTA) } & 3.00 & 2 \\ \text { Probability analysis } & 3.57 & 7 & \begin{array}{l}\text { Hazard and operability } \\ \text { studies (HAZOP) }\end{array} & 2.50 & 2 \\ \begin{array}{l}\text { "In house" decision-making } \\ \text { techniques and tools }\end{array} & 3.56 & 9 & \text { Hazard analysis (HAZAN) } & 2.50 & 2 \\ \begin{array}{l}\text { ICB (International Competence } \\ \text { Baseline) }\end{array} & 3.50 & 6 & \begin{array}{l}\text { Agile project management } \\ \text { methodologies }\end{array} & 1.00 & 1 \\ \begin{array}{l}\text { Communities of practice enabling } \\ \text { tools (professional forums etc.) }\end{array} & 3.45 & 11 & & \\ \begin{array}{l}\text { Organizational breakdown } \\ \text { structure - OBS }\end{array} & 3.40 & 5 & & \\ \begin{array}{l}\text { Precedence diagram method - } \\ \text { PDM }\end{array} & 3.33 & 9 & & \\ \text { Risk register } & & & & & \\ \end{array}$

\section{Discussion}

Conducted survey revealed interesting results. Based on respondents' answers in the first part of the survey it was stated that $84 \%$ of respondents do not consider methodologies, standards, and MTTs used in managing water projects adequate to fulfil needs of water sector. Even $94 \%$ of respondents think that certain problems in managing water projects may be minimized by the usage of more adequate methodologies, standards, or MTTs than the ones being used. In other words, most of the examined project managers think that there is an evident gap between methodologies, standards and MTTs being used and those that would be of real help when dealing with problems on projects. The possible reasons for this gap may be found in inadequate education on maximization of possibilities' usage that those tools may provide, in project procedures that do not cope with realistic situation on projects (gap between theory and praxes), psychological or time-constraining reluctance in learning, developing, testing or accepting new solutions, missing of new and creative solutions that would be custom-made and combine benefits of old solutions with an answer to new needs, etc. These findings and possible causes lying beneath them may be of great significance in conducting a future research on the field.

All respondents use integrated groupware, MS Excel and progress meetings, which is to certain extant similar with results of [14], who, among others, found progress reports and PM software used by all respondents in their research. Thereby, the average grade of usefulness of the meetings is 3.90, MS Excel 4.29, and integrated groupware 4.39. Authors believe that these figures are not as big as they could be compared to the wide usage of those methods. What can be done in order to increase them is to adopt principals of meeting management, maximize possibilities of MS Excel by enhancing the level of users' knowledge, and explore further possibilities of cloud management or multidimensional decision-making investment approach on web-based project management solutions in general [15]. In addition, project managers most often use cost benefit analyses and project goals charters, which is not surprising, since those elements are often mandatory when applying project for some sort of outer financing models, such as those provided by the European Union or World Bank. Water projects are of large financial, time and complexity nature, so state usually cannot fund them completely. Following application process for funds requires usage of these and similar tools, making of risk assessments, and regular reporting.

Reporting on project progress and project issues is immanent to any construction project, especially the complex infrastructural ones, with a large number of stakeholders that all require precise information on timely manner. Reporting systems and progress reports are therefore a must have element, but could strive for improvements, due to the comparison of their usage and grades of their usefulness. Also, when having in mind purpose of reporting systems, a parallel with rather poor usage of communication plans and extremely poor usage of stakeholder analysis must be drown. This finding indicates the possibility that project managers in Croatia adopt those tools that are on some level (e.g. state, funding, company) mandatory, without maximization of the purpose and objectives of their usage. Only $9.7 \%$ of respondents use stakeholder analysis (which among other objectives, has a cause to detect who on project 
Mariela Sjekavica Klepo, et al. / Proceedings of the Creative Construction Conference (2019) 070 https://doi.org/10.3311/CCC2019-070

needs what kind of information in order to engage their influence and underline what is important to them - i.e. to detect effective communication strategy towards different stakeholders, which can then be transmitted in more details through communication plan and integrated as a part of reporting system on a project).

The similar phenomenon may be seen in usage of Gantt charts and S curves - they still remain a traditional tool when on area of project management. However, authors suspect an inadequate usage of their possibilities, especially because work breakdown structure (which should precede a creation of a Gantt chart) or critical path method (which is basically a logic behind a Gantt chart as such) is rather modestly used. Their possibilities may be seen in [16], who found out that S-curve', 'forecasting techniques', 'cost control software products' and 'Work Breakdown Structure' are the popular tools and techniques used for cost control in megaprojects.

When considering modestly usage, relatively small number of respondents in the first group (13) use lessons learned technique, which has an extremely high grade of usefulness. This may stress the need of establishing Project Management Offices within companies that will be in charge for data collection, data analysis and recommendations' distribution within project management procedures, methodologies, tools and project management environment overall.

Managing project environment is quite neglected in general. Decision trees, already mentioned stakeholder analyses, "what-if" scenario analysis, SWOT analysis and risk management tools are rarely used. These indicates that project managers do not perceive possible outcomes of their decisions and outer influences on their projects on adequate manner. When it comes to risk management, similar results may be found in [17], whose study in Australian construction sector provided evidence that many of the tools promoted by the risk standards/associations do not seem to reflect current project manager practice.

When making decisions, an interesting information is the one of high grading of „other decision making techniques and tools". Out of all decision-making techniques and tools that were offered to choose from, respondents graded the "others" category the highest. This may be one more evidence on the need of development of traditional decisionmaking tools.

When it comes to project management software, respondents most frequently use MS Excel and Primavera, often use MS Project also, and are less keen to usage of other IT tools.

Speaking of project management methodologies and standards, respondents mostly use those developed "in house". They often use ICB, and rarely PMBOK or ISO Guidance on Project Management. No one uses other methodologies (PRINCE, PRINCE 2, P2M/KPM, etc.). Still, 19\% of respondents that use ICB as the most widespread methodology is a relatively small figure, regarding the impact ICB has on project success [18].

What can be seen in overall is that relatively small number of project management methodologies, standards and MTTs are being used on adequate manner. The reason staying behind this may be found in the belief of $84 \%$ of respondents do not consider methodologies, standards and MTTs used in managing water projects adequate to fulfil needs of the sector. In other words, if used project management solutions would concentrate on the things that really do make difference on projects, it would be reasonable to expect that usage and usefulness of those solutions would contribute to more competent project management, as well as more successful project outcomes. For instance, traditional tools such as Gantt charts, S curves, project goals charters and cash flow analysis do not have high grades in sense of usefulness, as authors had expected. However, a large number of respondents use them, possibly due to habits or official project procedures. This suggests that there is an area of contribution to development of useful, more custom based tools for managing projects, which could overcome disadvantages of existing implemented solutions.

Limitations of this study are few. First, this study has been made within a national context and on one type of infrastructural projects. Nevertheless, recommendations drawn out of it may be useful for regionally, mentality and industrially close countries. Although not much optimistic, the results of this research should not be run away from. These results are rough presentation of reality of construction project management in Croatia, where project management has relatively recently been legally recognized as an official role in construction on the one hand, and 
Mariela Sjekavica Klepo, et al. / Proceedings of the Creative Construction Conference (2019) 070 https://doi.org/10.3311/CCC2019-070

where construction companies mostly strive to survive on the market, on the other hand. By neglecting project management as such and labelling it as "one more problem to deal with within company", construction practitioners often omit the fact that project management is not the problem, but the solution to existing problems. As stated by [19] when referring to project management situation in India - construction industry lacks a structure or pattern, which can be provided by the tools such as project management. This is a general conclusion that may be extracted and used regardless the research limitations. Further, regardless the limitation of this study, the idea behind this research as well as its results may be served as a pilot study in building a larger platform for conducting analogous or similar research on the field, whether in multinational or multisector sense, or both.

\section{Conclusion}

This study investigated usage and perceived usefulness of project management MTTs in infrastructure projects in the Republic of Croatia, on an example of projects from water sector. The results showed an existing gap between used and useful/efficient project management MTTs. Further research may be undertaken to discover reasons standing behind this gap and/or to build up a research platform combining several countries and types of construction projects.

\section{Acknowledgements}

Authors would like to thank Croatian waters and Alma Mater Europea ECM for support and motivation of this research.

\section{References}

[1] W.J. Kettinger, J.T.C. Teng, S. Guha, Business Process Change: A Study of Methodologies, Techniques, and Tools, MIS Quart. March (1997) 55-80. https://doi.org/10.2307/249742

[2] R.A. Lordo, Learning from Data: Concepts, Theory, and Methods, Technometrics. 43 (1) (2001) 105-106.

[3] M. Radujković, M. Sjekavica, Project Management Success Factors, Procedia Engineer. 196 (2017) 607-615. https://doi.org/10.1016/j.proeng.2017.08.048

[4] M. Špundak, Mixed agile/traditional project management methodology - reality or illusion?, Procd. Soc. Behv. 119 (2014) 939 - 948. https://doi.org/10.1016/j.sbspro.2014.03.105

[5] Project Management Institute, Project Management Body of Knowledge (PMBOK) Guide and Standards, $5^{\text {th }}$ ed., Project Management Institute, Upper Darby, Philadelphia, 2013.

[6] International Project Management Association, ICB - IPMA Competence Baseline, $3^{\text {rd }}$ ed., International Project Management Association, Nijkerk, 2006.

[7] J. Fortune, D. White, K. Jugdev, D. Walker, Looking again at current practice in project management, International Journal of Managing Projects in Business. 4(4) (2011) 553-572. https://doi.org/10.1108/17538371111164010

[8] K. Jugdev, D. Perkins, J. Fortune, D. White, D. Walker, An exploratory study of project success with tools, software and methods, International Journal of Managing Projects in Business. 6(3) (2013) 534-551. https://doi.org/10.1108/IJMPB-08-2012-0051

[9] P. Patanakul, B. Iewwongcharoen, D. Milosevic, An empirical study on the use of project management tools and techniques across project lifecycle and their impact on project success, J. Gen. Manage. 35(3) (2010) 41-65. https://doi.org/10.1177/030630701003500304

[10] M. Radujković, D. Car Pušić, N. Ostojić Škomrlj, M. Vukomanović, I. Burcar Dunović, D. Delić, H. Meštrović, H., Planiranje i kontrola projekata (Project planning and control), University of Zagreb, Faculty of Civil Engineering, Zagreb, 2012.

[11] C. Drob, V. Zichil, Overview regarding the main guidelines, standards and methodologies used in project management, Journal of Engineering Studies and Research. 19 (3) (2013) 26-31. https://doi.org/10.29081/jesr.v19i3.113

[12] M. Ferreira, A. Tereso, P. Ribeiro, G. Fernandes, I. Loureiro, Project Management Practices in Private Portuguese Organizations, Proc. Techn. 9 (2013) 608-617. https://doi.org/10.1016/j.protcy.2013.12.067

[13] M. Sjekavica, Early warning system in managing construction projects, Doctoral dissertation, University of Zagreb, Faculty of Civil Engineering, Zagreb, 2017.

[14] C. Besner, B. Hobbs, B., Project management practice, generic or contextual: a reality check, Proj. Manag. J. 39 (1) (2008) 16-33. h ttps://doi.org/10.1002\%2Fpmj.20033

[15] M.J. Skibniewski, L. Zhang, L., Economic Feasibility of Web-Based Project Management Solutions, International Journal of Construction Management. 5(1) (2005) 103-121. https://doi.org/10.1080/15623599.2005.10773070

[16] B.-G. Hwang, M. Shan, L. Zhu, W.-C. Lim, Cost control in megaprojects: efficacy, tools and techniques, key knowledge areas and project comparisons, International Journal of Construction Management (2018) (in press).

[17] J. Jepson, K. Kirytopoulos, K. London, Insights into the application of risk tools and techniques by construction project managers, International Journal of Construction Management (2018) (in press). http://dx.doi.org/10.1080/15623599.2018.1484976

[18] M.M. Nahod, M. Vukomanović, M. Radujković, The Impact of ICB 3.0 Competences on Project Management Success, Procd. Soc. Behv. 74 (2013) 244 - 254. https://doi.org/10.1016/j.sbspro.2013.03.014

[19] A. Auti, M. Skitmore, Construction Project Management in India, International Journal of Construction Management. 8(2) (2008) 65-77. https://doi.org/10.1080/15623599.2008.10773116 